\title{
Comparative study of idursulfase beta and idursulfase in vitro and in vivo
}

\author{
Chihwa Kim ${ }^{1}$, Jinwook $\mathrm{Seo}^{2}$, Yokyung Chung ${ }^{2}$, Hyi-Jeong Ji ${ }^{3}$, Jaehyeon Lee ${ }^{2}$, Jongmun Sohn², Byoungju Lee ${ }^{2}$ \\ and Eui-cheol Jo ${ }^{1}$
}

Hunter syndrome is an X-linked lysosomal storage disease caused by a deficiency in the enzyme iduronate-2-sulfatase (IDS), leading to the accumulation of glycosaminoglycans (GAGs). Two recombinant enzymes, idursulfase and idursulfase beta are currently available for enzyme replacement therapy for Hunter syndrome. These two enzymes exhibited some differences in various clinical parameters in a recent clinical trial. Regarding the similarities and differences of these enzymes, previous research has characterized their biochemical and physicochemical properties. We compared the in vitro and in vivo efficacy of the two enzymes on patient fibroblasts and mouse model. Two enzymes were taken up into the cell and degraded GAGs accumulated in fibroblasts. In vivo studies of two enzymes revealed similar organ distribution and decreased urinary GAGs excretion. Especially, idursulfase beta exhibited enhanced in vitro efficacy for the lower concentration of treatment, in vivo efficacy in the degradation of tissue GAGs and improvement of bones, and revealed lower anti-drug antibody formation. A biochemical analysis showed that both enzymes show largely a similar glycosylation pattern, but the several peaks were different and quantity of aggregates of idursulfase beta was lower.

Journal of Human Genetics (2017) 62, 167-174; doi:10.1038/jhg.2016.133; published online 10 November 2016

\section{INTRODUCTION}

Mucopolysaccharidosis II (MPS II, Hunter syndrome; OMIM 309900) is an X-linked lysosomal storage disease (LSD) caused by a deficiency in the enzyme iduronate-2-sulfatase (IDS), leading to the accumulation of glycosaminoglycans (GAGs) within lysosomes. MPS II is progressive and multisystemic, with significant morbidity and early mortality. The clinical spectrum is divided into severe and attenuated forms according to the presence of cognitive impairment. The clinical features include coarse facial features, recurrent ear and respiratory infections, hearing loss, airway obstruction and restriction, cardiac valvular diseases, hepatosplenomegaly, skeletal abnormalities, growth restriction, joint stiffness and neurological complications.

The treatment of MPS II was palliative before the introduction of enzyme replacement therapy (ERT). However, successful clinical trials ${ }^{1-3}$ have led to the approval of ERT with idursulfase by the United States Food and Drug Administration in July 2006 and with idursulfase beta by the Korea Food and Drug Administration in January 2012. Therefore, these recombinant enzymes are currently available for ERT for patients with MPS II. These two enzymes have $100 \%$ identical amino acid sequences derived from the human IDS gene (NM_000202). IDS protein (EC 3.1.6.13) is a glycoprotein required for the lysosomal degradation of heparan sulfate and dermatan sulfate. The characterization of IDS protein purified from the human liver was reported. ${ }^{4}$ The IDS protein consists of 550 amino acids, including a 25 -amino acid signal peptide, which is cleaved in the secreted protein and contains eight $\mathrm{N}$-linked glycosylation sites at positions 31, 115, 144, 246, 280, 325, 513 and 537. All these glycosylations can be utilized for cellular internalization and lysosomal targeting via the mannose-6-phosphate receptor (M6PR)-mediated pathway. ${ }^{5-7}$ Sulfatase family enzymes are members of a highly conserved family and have a unique post-translational modification, formylglycine (FGly), that is crucial for sulfate ester cleavage. ${ }^{8,9}$ This modification occurs in the endoplasmic reticulum via the action of formylglycine-generating enzyme which converts a conserved cysteine residue into a 2 -amino-3-oxopropionic acid residue. ${ }^{10}$ This modification in the IDS protein occurs in the cystein-84 residue, thus activating the protein. ${ }^{11}$

In a preclinical study, idursulfase was useful in the treatment and management of MPS II, ${ }^{12}$ and idursulfase beta $\left(0.5 \mathrm{mg} \mathrm{kg}^{-1}\right)$ was also effective in the reduction of GAGs in several tissues (unpublished data). The high-dose treatment of idursulfase beta prevented central nervous system damage in an MPS II mouse model. ${ }^{13}$

Idursulfase showed effect on reductions in urine GAGs levels and organ size and increased changes in a six-minute walking test (6-MWT) in clinical studies. ${ }^{2,3}$ Anti-drug antibodies were detected in approximately $50 \%$ of patients who received ERT with idursulfase, but anti-idursulfase IgE antibodies were not detected. ${ }^{2,14,15}$ However, recent study reported IgE-mediated anaphylaxis and allergic reactions to idursulfase. ${ }^{16}$ A phase I/II clinical trial indicated that idursulfase beta generates a clinically significant reduction of urinary GAGs and

${ }^{1}$ Protein Engineering Laboratory, MOGAM Institute for Biomedical Research, Yongin, Republic of Korea; ${ }^{2}$ Research Center, Green Cross Corporation, Yongin, Republic of Korea and ${ }^{3}$ Corporate Development, Green Cross Corporation, Yongin, Republic of Korea

Correspondence: Dr C Kim, Protein Engineering Laboratory, MOGAM Institute for Biomedical Research, 93 Ihyeon-ro, Giheung-gu, Yongin-si, Gyeonggi-do 16924, Republic of Korea. E-mail: chkim@mogam.re.kr

Received 7 July 2016; revised 8 September 2016; accepted 30 September 2016; published online 10 November 2016 
improvements in endurance as measured by a 6 -MWT. ${ }^{1}$ Anti-drug IgG antibodies were detected in 10 patients at baseline, which was generated by previous idursulfase treatment; therefore, there were no newly detected antibodies to idursulfase beta. ${ }^{1}$

In view of this background, two enzymes have already been compared in biochemical and physicochemical examinations, ${ }^{17}$ and several differences are summarized in Supplementary Table 1. For more study, we compared the in vitro efficacy of these two recombinant enzymes. Because FGly content and enzyme activity directly affect substrate degradation, we used Hunter patients' fibroblasts of both Koreans and Caucasians to compare the reduction of GAGs in lysosomes. Also, the long-term study of two enzymes with the $1 \mathrm{mg} \mathrm{kg}^{-1}$ dosage was evaluated for immunogenicity and various efficacies in IDS KO and IDS-tolerant mouse model.

\section{MATERIALS AND METHODS}

\section{Idursulfase and Idursulfase beta}

Idursulfase (Shire Human Genetic Therapies, Lexington, KY, USA), as a liquid formulation with a concentration of $2 \mathrm{mg} \mathrm{ml}^{-1}$, was purchased from Myoderm (Norristown, PA, USA). Idursulfase beta (Green Cross Corp, Yongin, Korea), also a liquid formulation with a concentration of $2 \mathrm{mg} \mathrm{ml}^{-1}$, was provided by Green Cross Corporation (Yongin, Korea) for analysis.

\section{MPS II patient fibroblasts}

To compare enzyme efficacy at the cellular level, nine fibroblasts were used. Fibroblast cell lines of five Korean Hunter patients (KH17, KH30, KH38, KH54 and KH69) have been utilized ${ }^{18}$ in a mutation study by the Samsung Medical Center (Seoul, Korea) and approved for use by an Institutional Review Board of the Samsung Medical Center. Fibroblasat cell lines of four Caucasian Hunter patients (GM00615, GM01929, GM02268 and GM13203) were provided by the Coriell Institute (Camden, NJ, USA). All fibroblasts were expanded, cryopreserved, and used within 15 passage numbers.

\section{IDS knockout animals}

The development and characterization of the IDS knockout (KO) mouse model has been previously described. ${ }^{19}$ IDS KO mice were produced by replacing exon 2 and 3 of the IDS gene with the neomycin resistance gene. The genotype of all mice used in these experiments was assessed by PCR of genomic DNA isolated from the tail. The animal study was approved by the Institutional Animal Care and Use Committee (IACUC) and mice were maintained in specific pathogenfree conditions at the animal facility of the Green Cross Corporation and Samsung Biomedical Research Institute (Seoul, Korea).

\section{Generation of immune tolerant mice (IDS ${ }^{\text {C84Ttg) }}$}

Human IDS cDNA with a C84T mutation (cysteine residue converted to threonine at 84 positions) was cloned into an expression vector. A targeting vector was linearized and introduced into the mouse zygote by microinjection. The offspring was analyzed for the IDS gene in their chromosomal DNA by PCR and Western blot. Positive offspring were maintained through crossing with C57BL/6 mouse. To remove the mouse IDS protein level and obtain the tolerant mouse (IDS ${ }^{-1-\mathrm{C} 84 \mathrm{Ttg}}$ ), IDS $^{\mathrm{C} 84 \mathrm{~T}}$ transgenic (Tg) mice were bred with IDS KO mice. Tolerant mice were screened by genotyping with PCR and used for immunogenicity studies. The study was approved by the IACUC and mice were maintained in specific pathogen-free conditions at the animal facility of the Green Cross Corporation.

\section{Enzyme kinetics of IDS proteins}

The activity was measured by the fluorometric assay using 4-methylumbelliferyl-alpha-L-iduronide-2-sulfate- $\mathrm{Na}_{2}$ (4-MU- $\alpha$ IdoA-2S, TRC, ON, Canada) and by determining the rate of enzyme-catalyzed hydrolysis of substrate in $50 \mathrm{~mm}$ of soduim acetate, $0.5 \mathrm{mg} \mathrm{ml}^{-1}$ bovine serum albumin, pH5.5. The released 4methylumbelliferyl (4-MU) was quantified by reading fluorescence at excitation $355 \mathrm{~nm}$ and emission $460 \mathrm{~nm}$ using a Victor 4 reader (Perkin Elmer, Waltham, MA, USA) against a 4-MU (Sigma, St Louis, MO, USA) standard curve. ${ }^{17,20}$ The kinetic parameters for each substrate were based on measurements at nine concentrations, and a Michaelis-Menten saturation curve was used to calculate $K_{\mathrm{m}}$ and $V_{\max }$ values. $K_{\text {cat }}$ is defined as turnover number and denotes the maximum number of enzymatic reactions catalyzed per unit time.

\section{Cell staining}

Confocal microscopy was performed with the Hunter fibroblasts, which were grown overnight in DMEM with $10 \%$ fetal bovine serum (FBS) to $>50 \%$ confluency on glass slides (Marienfeld-Superior, Lauda-Königshofen, Germany). Two enzymes ( $40 \mathrm{~nm}$ ) were added to the cells for $24 \mathrm{~h}$, respectively. Cells were fixed and permeabilized. The slides were blocked with $10 \%$ normal goat serum (NGS, Invitrogen, NY, USA) in $0.1 \%$ Triton X-100 at room temperature for one hour. IDS B-5 (Santa Cruz, TX, USA) as a primary antibody and PE-labeled anti-mouse IgG (1:100, Santa Cruz) as a secondary antibody were treated for one hour for IDS protein staining. For heparan sulfate (HS) staining, FITC-labeled anti-HS antibody (10E4, 1:50, US Biological, MA, USA) was added and incubated for $1 \mathrm{~h}$. The washed slides were treated with Hoechst 33342 (1:2000, Thermo, Rockford, IL, USA) for nuclear staining and mounted with a mounting medium (DAKO, Glostrup, Denmark). Confocal microscopy was performed with a LSM 700 inverted fluorescence microscope (Carl Zeiss, Oberkochen, Germany).

\section{Cellular uptake}

To perform a valid comparison of the cellular uptake activity, both enzymes were analyzed. Normal human fibroblasts (CCD-96Sk, ATCC, Manassas, VA, USA) and patient fibroblasts were grown to confluency in a T-175 flask using IMDM for normal cells and DMEM (Invitrogen) or EMEM (Lonza, Allendale, NJ, USA) for patient cells with 10\% FBS supplementation, respectivley. The cells were washed with phosphate-buffered saline (PBS) and seeded at $3 \times 10^{5}$ cells per well in a 12 -well plate. The plates were incubated overnight at $37^{\circ} \mathrm{C}$. Following incubation, the enzymes were diluted in media with 5\% FBS and added to the cells. In the M6PR-mediated uptake assay, idursulfase beta (2, 8 and $32 \mathrm{~nm}$ ) with mannose-6-phosphate (0.2, 1 and $5 \mathrm{~mm}$ ) (Sigma) were treated for 3, 6, 12 and $24 \mathrm{~h}$. The cells were washed and lysed with a lysis buffer and a mammalian protein extraction reagent (M-PER) (Thermo). The cell lysates were frozen at $-20^{\circ} \mathrm{C}$ for the next analysis. Total protein concentration was measured by the BCA method (Pierce, Rockford, IL, USA) and quantification of the IDS proteins taken up by the cells was performed on the cell lysates using an enzyme-linked immunosorbent assay (ELISA). The concentration of each enzyme representing the half-maximal uptake was measured and defined as $K_{\text {uptake. }}$

\section{Biodistribution}

Male C57BL/6 mice received a single intravenous administration of idursulfase and idursulfase beta at $1 \mathrm{mg} \mathrm{kg}^{-1}$, respectively ( $n=3$ per group). The enzymetreated mice were sacrificed two hours post-dose. Tissues of the brain, lung, heart, liver, spleen, kidney (left and right, respectively), and mesenteric lymph node were collected and frozen immediately in liquid nitrogen. All tissues were prepared by homogenization in lysis buffer (Cell Signaling, Danvers, MA, USA) using a motorized tissue homogenizer. Supernatants were collected after centrifugation and assayed for total protein concentration by BCA and IDS protein concentration by ELISA.

\section{Quantification of IDS protein}

The IDS concentration of cell lysate and tissue extract was analyzed by ELISA. First, 96-well plates were coated with anti-IDS antibody $\left(1 \mu \mathrm{g} \mathrm{m}^{-1}, \mathrm{R} \& \mathrm{D}\right.$ systems, Minneapolis, MN, USA) in PBS overnight at $4{ }^{\circ} \mathrm{C}$. After a washout, blocking was performed with $1 \%$ BSA in PBS at room temperature for one hour. Following three washes in PBS-T (Tween-20, 0.1\%), cell lysate or tissue extracts were diluted (1:50 or 1:100) in blocking buffer and incubated at room temperature for two hours. Plates were washed thrice and then incubated with biotin-labeled anti-IDS antibody (R\&D systems) for one and half hours at room temperature. Following three washes in PBS-T, HRP-conjugated streptavidin (Sigma) was added to each well and incubated for one hour. TMB peroxidase substrate (KPL, Gaithersburg, MD, USA) was added to each well for $15 \mathrm{~min}$. Reaction was stopped following the addition of sulfuric acid, and absorbance was read at $450 \mathrm{~nm}$. IDS concentration was adjusted for total protein concentration. 


\section{Reduction of intracellular GAG storage}

Cultured fibroblasts were labeled with ${ }^{35} \mathrm{SO}_{4}$ as described elsewhere. ${ }^{21,22}$ Briefly, cultured fibroblasts were starved with serum- and sulfate-free DMEM (Welgene, Gyeonsan-si, Korea) for one day and incorporated with ${ }^{35}$ S-radioisotope-labeled $\mathrm{Na}_{2}{ }^{35} \mathrm{SO}_{4}(20 \mu \mathrm{Ci}$, Perkin Elmer $)$ in sulfate-free DMEM containing $8 \%$ dialyzed FBS for 2 days. After that, radioisotopelabeled fibroblasts were treated with idursulfase and idursulfase beta for $24 \mathrm{~h}$ in DMEM containing 5\% FBS. Cells were washed in PBS before and after trypsinization. Pellets were suspended in $0.2 \mathrm{M}$ sodium phosphate $(\mathrm{pH}$ 6.4) and were frozen and thawed several times. Radiolabeled GAGs were measured via a micro beta counter (Perkin Elmer) after adding $2 \mathrm{ml}$ of a cocktail solution (Optiphase supermix, Perkin Elmer) to each tube.

\section{Urinary and tissue GAGs measurement}

Urine samples were collected before infusion and every four weeks after infusion. Tissue extract was prepared by homogenizing tissue in PBS with sonication. Homogenates were incubated overnight at $4{ }^{\circ} \mathrm{C}$ with rotation. Tissue debris was pelleted by centrifugation at 12000 r.p.m. for $10 \mathrm{~min}$, and supernatants were collected and assayed for total protein concentration by BCA and GAGs assays. GAGs concentration in urine and tissue was quantified by colorimetric assay using alcian blue dye (Kamiya, Tukwila, WA, USA).23,24 Urinary GAGs concentration was adjusted for creatinine concentration (Sigma) and tissue GAGs levels were adjusted for total protein concentration.

\section{Detection of anti-drug antibody}

Briefly, 96-well ELISA plates were coated with $10 \mu \mathrm{g} \mathrm{ml}^{-1}$ of IDS protein (idursulfase or idursulfase beta) in PBS overnight at $4{ }^{\circ} \mathrm{C}$. Plates were washed thrice with PBS and blocking was performed with $1 \%$ BSA in PBS at room temperature for $1 \mathrm{~h}$. Following three washes in PBS-T, plasma samples were diluted (1:20 1:10 000) in blocking buffer and incubated at room temperature for two hours. Plates were washed three times and then incubated with HRP-conjugated anti-mouse IgG (R\&D systems) for one and half hours at room temperature. Following three washes in PBS-T, TMB peroxidase substrate (KPL) was added to each well for $15 \mathrm{~min}$. The reaction was stopped following the addition of $1 \mathrm{~N}$ sulfuric acid, and the absorbance was read at $450 \mathrm{~nm}$. Results were reported as titers.

\section{Biochemical analysis}

Glycan mapping was carried out by releasing the glycans from the peptide backbone using PNGase F digestion and MALDI-MS measurement. The samples were rebuffered against $50 \mathrm{~mm}$ ammonium bicarbonate using ultrafiltration devices with a molecular cutoff of $10 \mathrm{kDa}$, and polysorbate 20 was removed using detergent removal spin columns. Data evaluation was performed with the software GlycoWorkbench 2.0 (http://www. glycoworkbench.org, generated by EUROCarbDB). The most prominent peaks were labeled and typically expected mammalian $\mathrm{N}$-glycosylation structures were assigned by database searching. Glycan linkage analysis was performed by gas chromatography/mass spectrometry (GC/MS). Analysis of protein aggregation was carried out by analytical ultra-centrifugation and size exclusion chromatography-multi-angle laser light scattering.

\section{Micro computed tomography}

In vivo micro computed tomography (micro $\mathrm{CT}$ ) imaging was performed using a micro CT (Inveon, Siemens, Knoxville, TN, USA). Each mouse was anesthetized with isoflurane in $\mathrm{O}_{2}$ and placed on the scanner bed in a prone position. The total scan time was $432 \mathrm{~s}$ during which the mouse was under anesthesia. The scans were performed using the following scanner settings: $\mathrm{X}$-ray source voltage $60 \mathrm{kVp}$, current $400 \mu \mathrm{A}$ and a $1.5-\mathrm{mm}$ thick aluminum

Table 1 Enzyme kinetics

\begin{tabular}{lcc}
\hline & Idursulfase beta & Idursulfase \\
\hline$K_{\mathrm{m}}(\mu \mathrm{M})$ & $370.54 \pm 10.57$ & $348.26 \pm 39.52$ \\
$K_{\text {cat }}\left(\mathrm{min}^{-1}\right)$ & $10946.27 \pm 560.97$ & $6702.20 \pm 882.27$ \\
\hline
\end{tabular}

filter to reduce beam-hardening artifact. The pixel size was $34.87 \mu \mathrm{m}$, the exposure time was $400 \mathrm{~ms}$, and the rotation step was $1^{\circ}$, with a complete rotation over $360^{\circ}$. The CT images were reconstructed using COBRA reconstruction software (Exxim Computing Corp., Pleasanton, CA, USA). The CT reconstruction protocol, which used a down sampling factor of 1 , was set to interpolate bilinearly using a Shepp-Logan filter. Image analysis software (Inveon) was used for visualization and analysis.

\section{Bone morphometric analysis}

The treatment effect of the enzymes was investigated by bone morphometric analysis. A cylinder that contained trabecular bone was selected in the metaphysis of the tibia and femur, and the bone volume was calculated. The bone volume fraction, which describes the ratio of bone volume to total volume, the trabecular thickness, bone surface area over bone volume, trabecular spacing, trabecular number and trabecular pattern factor were determined for the trabecular bone.

\section{Statistical analysis}

All values were expressed as the mean and s.d.s. Statistical analysis for all the experiments were performed using two-sample $t$-tests or $t$-tests, and $P$-values $<0.05$ were considered statistically significant. In in vivo analysis, the compression difference was compared between the wild-type (WT) and enzyme-treated groups and between enzyme-treated groups in some cases. If equal variance failed, Mann-Whitney rank sum tests were used. All analysis was performed with SigmaPlot version 12 (Systat Software, San Jose, CA, USA).

\section{RESULTS}

\section{Enzyme kinetics}

The specific enzyme activities of idursulfase beta and idursulfase were compared and reported, ${ }^{17}$ as determined by the fluorescence method using 4-methylumbelliferyl-alpha-L-idopyranosiduronic acid-2-sulfate as substrate, were $42.6 \pm 1.1$ and $27.8 \pm 0.9 \mathrm{nmol} \mathrm{min}{ }^{-1} \mu \mathrm{g}^{-1}$, respectively. The kinetics $\left(K_{\mathrm{m}}, K_{\mathrm{cat}}\right)$ of theses enzymes are summarized in Table 1 . Idursulfase beta exhibited a higher specific activity and $K_{\text {cat }}$.

\section{Cellular uptake}

Confocal microscopy of patient fibroblasts revealed that idursulfase beta and idursulfase were efficiently taken up into the cells (Figure 1a). To determine the impact of this treatment on receptor-mediated uptake, we examined M6PR-mediated uptake in normal fibroblasts (Figure 1b). When M6P was dose dependently added with idursulfase beta to normal cells for $24 \mathrm{~h}$, idursulfase beta exhibited decreased uptake in the presence of M6P. Similar to other lysosomal enzymes, idursulfase beta was taken up by the cell and lysosomes via the M6PR-mediated pathway. No difference in the uptake level was noted between normal and patient cells, which exhibited a similar M6PR expression level (Supplementary Figure 1). The uptake levels of the two enzymes were compared at a time-dependent manner in patient fibroblasts. Idursulfase beta exhibited faster uptake than idursulfase in two kinds of patient fibroblasts (Figures $2 \mathrm{a}$ and $\mathrm{b}$ ). The kinetics of the IDS enzyme after uptake was also determined by measuring the residual IDS concentration (Figure 2c). The degradation of two enzymes showed similar pattern and $\sim 40 \%$ of uptaken IDS remained after 6 days. There was no statistical significance at each time point between them. Intracellular enzyme activities after uptake also were measured (Supplementary Figure 2).

\section{Reduction of GAG storage in cells}

After the two enzymes are taken up into the cells, the enzymes travel to lysosomes and degrade accumulated GAGs. To compare the degradation of GAGs in patient fibroblasts following treatment with the two enzymes, GAGs were incorporated with a ${ }^{35} \mathrm{~S}$ - radioisotope. 
Nine Hunter patient fibroblasts were treated with various concentrations of two enzymes. Remaining intracellular GAGs levels show similar reduction rate in both treated groups, but idursulfase beta show more effective reduction activity at lower concentrations $(<312 \mathrm{pm})$ and this difference was statistically significant (Figures $2 \mathrm{~d}$ and e). The similar results were observed among Korean a

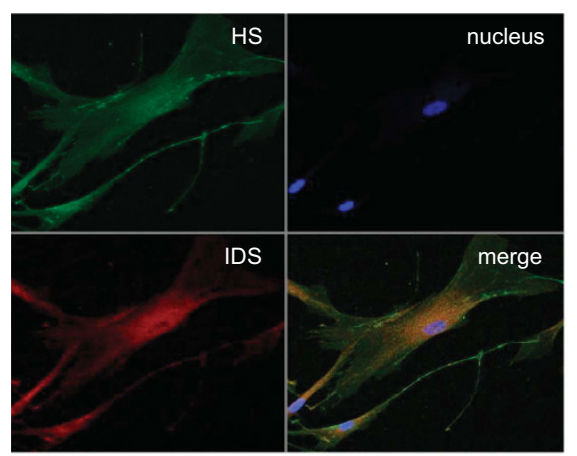

b

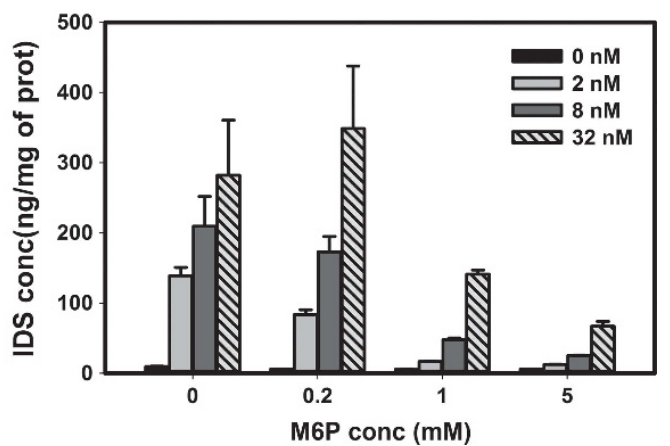

Figure 1 Cellular uptake of idursulfase beta. (a) Cells were incubated with idursulfase beta (40 nm) for $24 \mathrm{~h}$ and then fixed with $4 \%$ paraformaldehyde and stained with an antibody for HS (green), IDS protein (red) and nuclei (blue $\times 40$ ). (b) Normal fibroblasts were incubated with idursulfase beta (2, 8 and $32 \mathrm{~nm}$ ) with or without D-M6P $(0.2,1$ and $5 \mathrm{~mm})$ for $24 \mathrm{~h}$. Cells were lysed and IDS concentration in the lysate was analyzed by ELISA. Experiments were performed three times. Data are presented as averages, and error bars represent s.d.

a

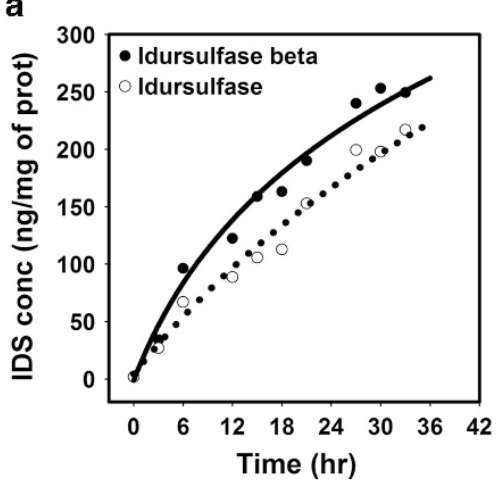

d

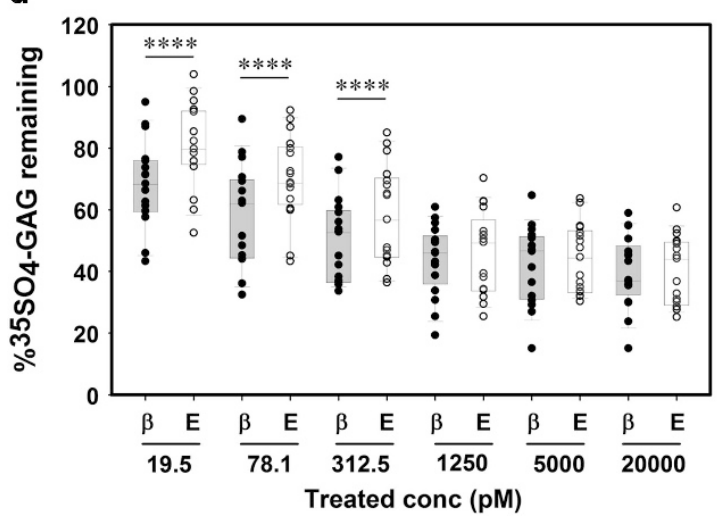

b

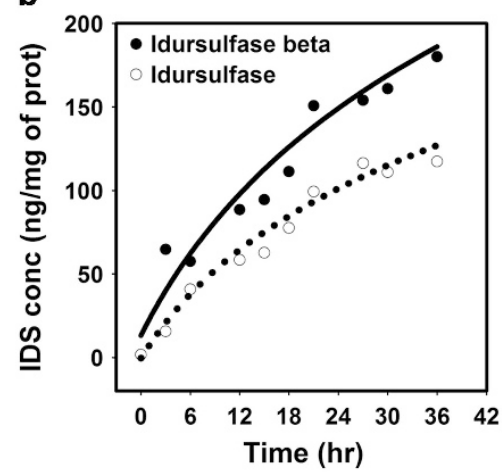

C

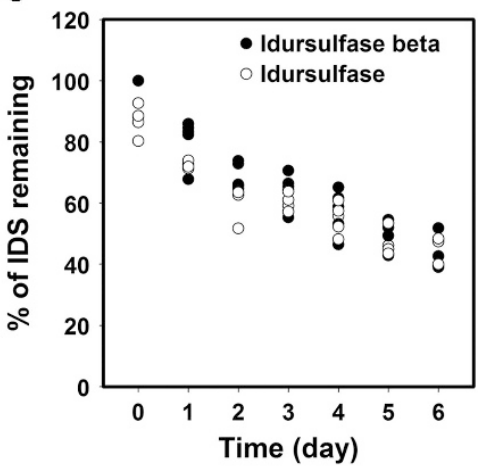

e

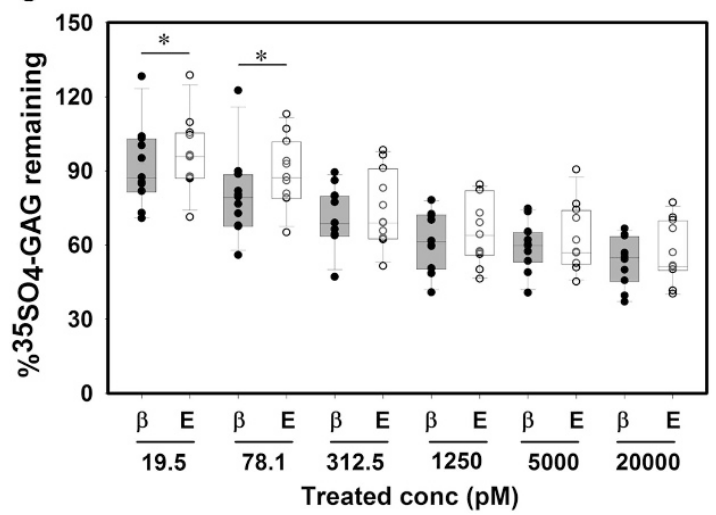

Figure 2 Cellular uptake and intracellular glycosaminoglycans (GAGs) reduction activity of the two enzymes. (a) KH38 and (b) GM00615 fibroblasts were treated with the two enzymes (40 nm) for 3, 6, 12, 15, 18, 21, 27, 30, 33 and $36 \mathrm{~h}$. These experiments were performed three times per fibroblast, and data are presented as average values. Idursulfase beta exhibited faster uptake than idursulfase in both fibroblasts. (c) To evaluate the degradation of enzymes at the intracellular level, iduronate-2-sulfatase (IDS) were treated for $24 \mathrm{~h}$, washed with PBS (three times), and cultured with fresh culture media without enzymes for 6 days. Cells (KH38, GM00615, GM01929 and GM13203) were collected every day at the same time. IDS concentrations were analyzed by ELISA method, and normalized total protein concentrations of cell lysates were measured by BCA assay. The IDS concentration remaining in the idursulfase beta-treated group at zero day was regarded as $100 \%$. (d) Five Korean patient fibroblasts were incorporated with ${ }^{35} \mathrm{SO}_{4}$ for 2 days and treated with idursulfase beta and idursulfase from 19.5 to 20000 pm for $24 \mathrm{~h}$. (e) Four Caucasian fibroblasts were treated equally. Whole-cell lysates were mixed with a cocktail, ${ }^{35} \mathrm{~S}$-labeled GAGs were read using a micro beta counter, and the resulting counts per minute (CPM) was compared. The CPM value of all data was calculated as a percentage to the CPM value of no treated fibroblast. $\beta$ represents idursulfase beta and $\mathrm{E}$ represents idursulfase. Dots indicate individual experimental data. All experiments performed three times per a fibroblast. Statistical significance was analyzed between the two groups. ${ }^{*} P<0.05$, $* * * * P<0.001$. 
and Caucasian Hunter patient fibroblasts. This result can be interpreted in the context of our results (Figures $2 \mathrm{a}$ and $\mathrm{b}$ ): the faster uptake and higher activity level of idursulfase beta could produce greater substrate degradation under the same conditions of treatment time and concentration.

\section{Organ distribution and in vivo efficacy}

The organ distribution of two enzymes following intravenous (IV) administration in WT male mice is presented in Table 2. All organs, except the kidney (left and right), contained similar amounts of enzyme administered, and the amount of idursulfase beta was higher in the kidney. Overall distribution pattern of two enzymes showed similar in all the organs except kidney, although the titer of idursulfase beta was always marginally higher than idursufase.

Table 2 Organ distribution of two enzymes following intravenous injection in normal mice

$$
\% \text { of injected dose, } 1 \mathrm{mg} \mathrm{kg}^{-1}
$$

\begin{tabular}{lcr} 
Organ & Idursulfase beta & \multicolumn{1}{c}{ Idursulfase } \\
\hline Brain & $0.017 \pm 0.002$ & $0.014 \pm 0.001$ \\
Lung & $0.193 \pm 0.047$ & $0.128 \pm 0.013$ \\
Heart & $0.132 \pm 0.023$ & $0.112 \pm 0.002$ \\
Liver & $17.669 \pm 8.376$ & $14.785 \pm 7.389$ \\
Spleen & $1.097 \pm 0.571$ & $0.884 \pm 0.175$ \\
Kidney-L & $0.587 \pm 0.055^{*}$ & $0.427 \pm 0.043$ \\
Kidney-R & $0.695 \pm 0.085^{*}$ & $0.488 \pm 0.061$ \\
mLN & $0.055 \pm 0.018$ & $0.0515 \pm 0.017$
\end{tabular}

All data were expressed as means \pm s.d. $N=3$ mice per group, ${ }^{*} P<0.05$.
Next, we evaluated the long-term (6 months) efficacy of $1 \mathrm{mg} \mathrm{kg}^{-1}$ idursulfase beta in IDS KO. We administered two enzymes intravenously into 7-week-old male mice (KO and WT), respectively. Urinary and tissue GAGs levels were measured and compared (Figures $3 \mathrm{a}$ and b). IDS KO mice treated with both enzymes showed that urinary GAGs excreted were greatly reduced to a degree observed in the WT mice, and maintained consistently low at all time points. The idursulfase beta- and idursulfase-treated groups exhibited reduced GAG levels in all tissues except the brain. Kidney and lung GAGs exhibited a statistically significantly greater reduction in the idursulfase beta-treated group.

When bone disease was compared between WT and KO mice, the femur and tibia of IDS KO mice (35 weeks old) showed increased levels of bone density, decreased bone surface, thicker trabeculae, and more narrow trabecular spacing than WT mice, but there was no difference in the average number of trabeculae per unit length (Figures $3 \mathrm{c}$ and $\mathrm{d}$ ). Bones of the femur and tibia of two enzymestreated IDS KO mice exhibited significantly reduced bone density and increased bone surface area, similar to the WT level. These mice exhibited increased trabecular space and thinned trabecular thickness after enzyme treatment (Figures $3 c$ and d; Supplementary Figure 3).

\section{Immunogenicity}

Following long-term treatment with the two enzymes, formation of anti-drug antibodies was analyzed in mouse plasma, which obtained before treatment and every 4 weeks after treatment. No antibodies were present in the vehicle-treated WT and IDS KO group. IDS KO animals that received idursulfase treatment exhibited significantly increased levels of plasma anti-drug IgG antibody (Figure 4a; Supplementary Figure 4). Antibody formation in the idursulfase group a

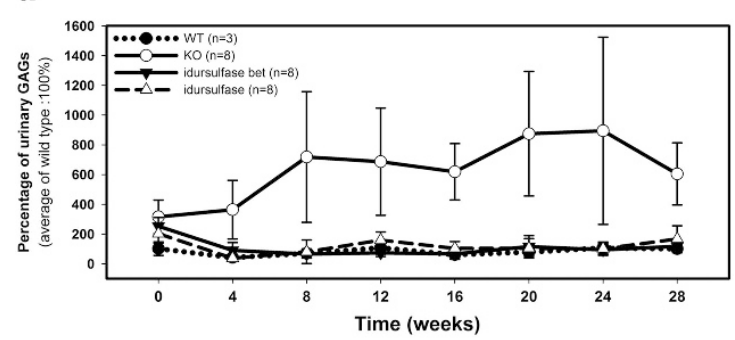

b

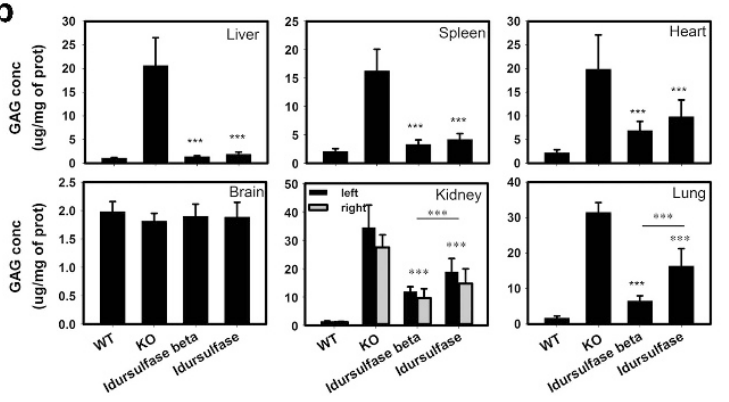

C
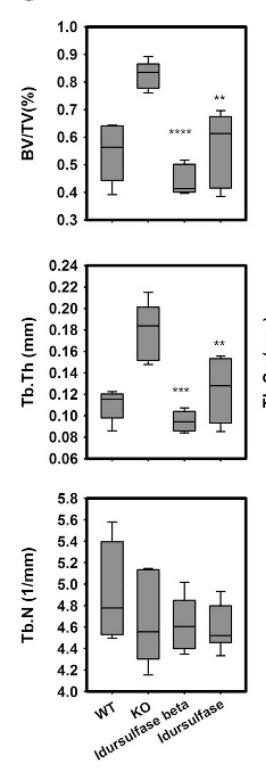
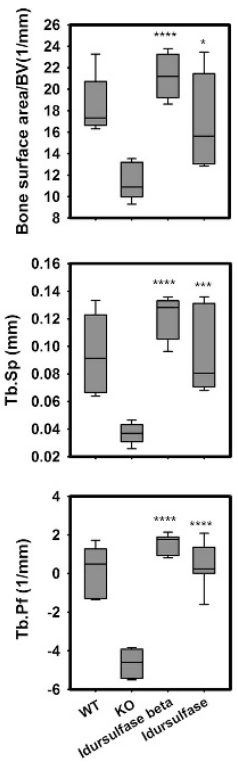

d
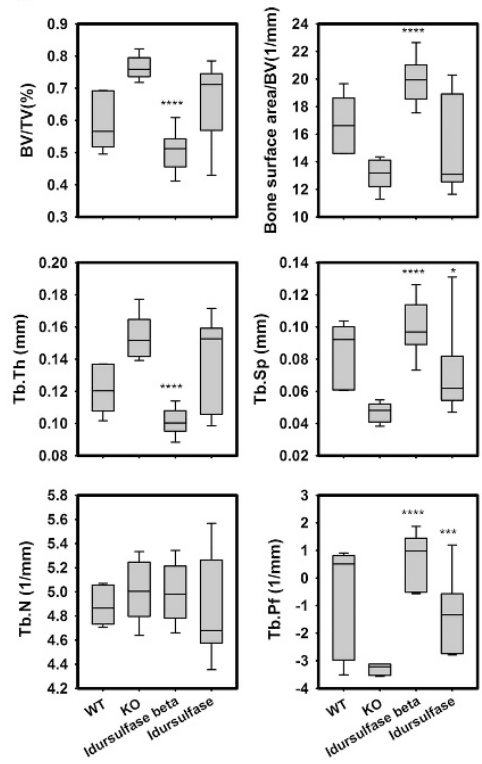

Figure 3 In vivo efficacy of two enzymes in the mucopolysaccharidosis II (MPS II) mouse model. Two enzymes administered by IV injection (1 mg kg-1) once a week for 6 months ( $n=8$ per group for vehicle-treated and enzymes-treated iduronate-2-sulfatase (IDS) knockout (KO), $n=3$ per group for wild-type (WT). (a) Urine was collected every four weeks using a metabolic cage. (b) Six types of organ tissue were isolated at sacrifice (29 weeks later). The glycosaminoglycans (GAGs) level of all urine and tissue samples were measured, which were normalized to the creatinine concentration of urine and total protein concentration in the tissue sample. All data were presented as averages, and error bars represent s.d. Micro CT analysis of the femur (c) and tibia (d) are presented and bone improvement was observed following long-term enzyme administration. The bone volume fraction, which describes the ratio of bone volume to total volume (BV/TV); the trabecular thickness (Tb.Th); bone surface area over bone volume (BS/BV); trabecular spacing (Tb.Sp); trabecular number (Tb.N); and trabecular pattern factor (Tb.Pf) were determined for the trabecular bone. Statistical significance was compared between the vehicle-treated IDS KO and each enzyme-treated IDS KO group. ${ }^{*} P<0.05,{ }^{* *} P<0.01,{ }^{* * *} P<0.005,{ }^{* * * *} P<0.001$. 
a

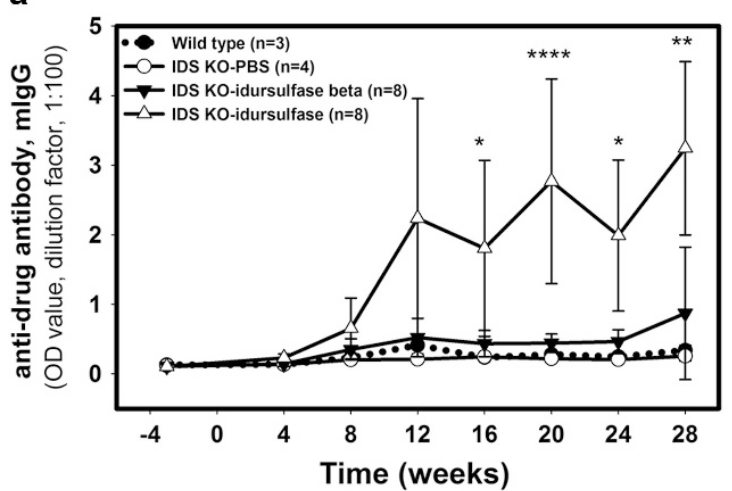

C

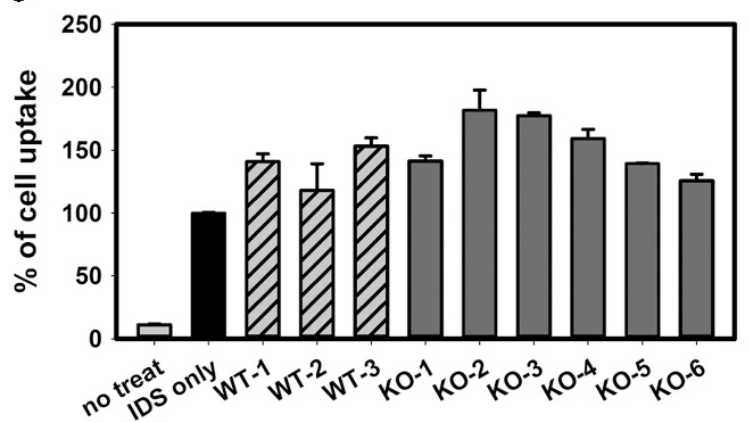

b

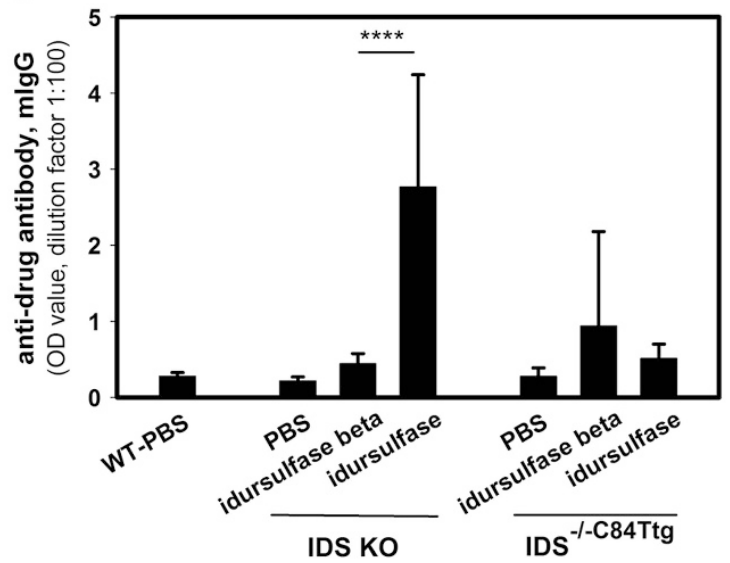

d

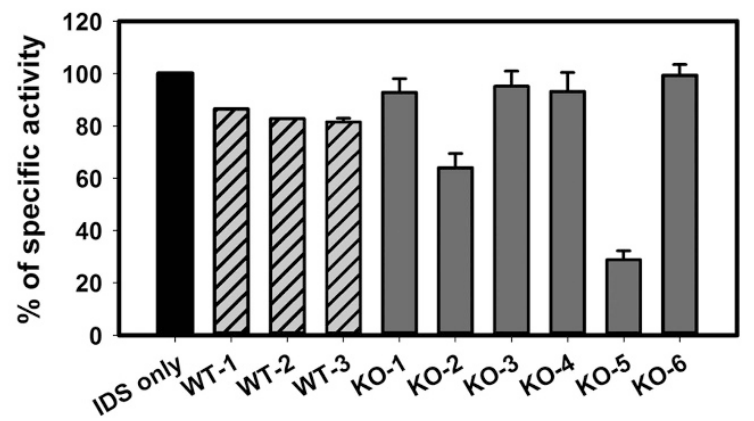

Figure 4 Anti-drug and neutralizing antibody formation analysis. Plasma was collected from each group every four weeks by eye bleeding. (a) Antibody titrations in diluted plasma (1:10 1:10 000) from wild-type (WT) and iduronate-2-sulfatase (IDS) knockout (KO) mice with or without enzyme treatment were compared and analyzed. Anti-drug antibodies in the idursulfase-treated group (six of eight mice) was generated. Data were presented as optical density (OD) values obtained with 1:100 dilution. Statistical comparisons were performed between idursulfase beta and idursulfase using student's $t$-test but failed the equal variance test. Thus, a Mann-Whitney rank sum test was performed. (b) The two enzymes were administered to IDS ${ }^{-1-C 84 T t g}$ tolerant mice for 6 months. Plasma was collected every four weeks, and antibody titration was analyzed. Data were presented as an OD value at 20 weeks (sample diluted 1:100). (c) The neutralizing effect of six types of antibodies was determined, KO-1 KO-6 samples represent anti-drug antibody positive plasma in idursulfase-treated group. Plasma of WT and six idursulfase-treated mice were added during cell uptake of IDS protein. Twenty-four hours later, IDS concentrations were measured in the cell lysate. The six antibodies did not affect cellular uptake. (d) In addition, plasma was added to determine the effect on catalytic activity of the enzyme. KO-2 and KO-5 plasma exhibited decreasing catalytic activity of the IDS protein. ${ }^{*} P<0.05,{ }^{* *} P<0.01,{ }^{* * * *} P<0.001$ versus idursulfase beta-treated group.

began to appear between 8 and 12 weeks after administration, and this status was maintained until the end of the analysis. Anti-drug antibodies were formed in six of eight mice, and neutralizing antibodies were determined by the inhibition of enzyme activity and cell uptake. No effect on cell uptake was noted (Figure 4c); however, two (KO-2 and KO-5) of six antibodies had no effect on cellular uptake, but neutralized or inhibited the specific activity of the IDS enzyme by 36 and $72 \%$, respectively (Figure $4 \mathrm{~d}$ ). We created IDS-tolerant mice to evaluate the various immunogenicity factors of the two enzymes. Tolerant mice are an in vivo tool commonly used to identify various factors. ${ }^{25-27}$ The tolerance of the mice created (IDS ${ }^{-/-C 84 T t g)}$ was confirmed: no anti-drug antibodies were found when the IDS protein was administered for 6 months (Supplementary Figure 5). In both enzyme-treated groups of $\mathrm{IDS}^{-/-\mathrm{C} 84 \mathrm{Ttg}}$ tolerant mice, the antibody response was not detected (Figure $4 \mathrm{~b}$ ).

\section{Biochemical characterization}

Biochemical properties of the two enzymes were compared because they were produced from different cell lines using different manufacturing processes. As MALDI-MS of PNGase $F$ released and permethylated N-glycans shows (Table 3; Supplementary Table 4), both enzymes exhibited similar qualitative patterns of $\mathrm{N}$-linked glycans which is dominated by complex-type glycans. In addition to complex-type glycans, both enzymes contained a few kinds of hybrid- and high-mannose-type glycans. Idursulfase beta contained only small amounts of high-mannose- and hybrid-type glycans, whereas idursulfase contained higher proportions of high-mannosetype glycans. Moreover, the fraction of complex-type glycans in idursulfase was characterized by an increased proportion of glycans with higher antennarity and sialic acid substitution. The idursulfase contained significantly less 4-GlcNAc (N-acetylglucosamine) than idursulfase beta, which was consistent with higher content of high-mannose-type glycans lacking GlcNAc in their antennae.

By analytical ultra-centrifugation, the main population, representing greater than $98.9 \%$ (idursulfase beta) and greater than $96.8 \%$ (idursulfase) of the protein content, was clearly assigned to the monomeric protein. The minor population likely represents dimer/ trimer and multimer, 0.8 and $0.3 \%$ for idursulfase beta and 1.8 and $1.4 \%$ for idursulfase, respectively. For idursulfase, higher quantity of aggregates $(3.2 \%)$ was detected than for idursulfase beta (1.1\%). With size exclusion chromatography-multi-angle laser light scattering analysis, a slightly larger void peak was noted for idursulfase, indicating an increased aggregate content compared with idursulfase beta. 
Table 3 List of glycan structure proposals for the most abundant peaks

\begin{tabular}{|c|c|c|}
\hline \multirow[b]{2}{*}{ Composition } & \multicolumn{2}{|c|}{ Enzymes } \\
\hline & Idursulfase beta & Idursulfase \\
\hline Hex5HexNAc2-2AB & ++ & +++ \\
\hline Hex3HexNAc4-2AB & +++ & ND \\
\hline Hex3HexNAc4dHex1-2AB & ++ & +++ \\
\hline Hex4HexNAc4-2AB & +++ & + \\
\hline Hex5HexNAc3dHex1-2AB & ND & +++ \\
\hline Hex6HexNAc3-2AB & ND & +++ \\
\hline Hex4HexNAc4dHex1-2AB & +++ & +++ \\
\hline Hex5HexNAc4-2AB & +++ & +++ \\
\hline Hex4HexNAc4-2AB & +++ & + \\
\hline Hex9HexNAc2-2AB & +++ & +++ \\
\hline Hex9HexNAc2-2AB & +++ & +++ \\
\hline Hex5HexNAc4dHex1-2AB & +++ & +++ \\
\hline Hex4HexNAc5dHex1-2AB & ++ & +++ \\
\hline Hex5HexNAc5dHex1-2AB & ND & +++ \\
\hline Hex6HexNAc5-2AB & ++ & + \\
\hline Hex6HexNAc5dHex1-2AB & ++ & +++ \\
\hline Hex7HexNAc6dHex1-2AB & ++ & +++ \\
\hline
\end{tabular}

Abbreviation: ND, not detected. Relative intensity, +++; >30\%, ++; 30\%, +; $<30 \%$.

\section{DISCUSSION}

Two recombinant enzymes, idursulfase beta and idursulfase, are available for the treatment of Hunter syndrome. They have the same amino acids but have slightly different glycosylation patterns because they are produced in different cell lines and have different manufacturing process. Idursulfase is produced in human fibrosarcoma cell line whereas idursulfase beta is produced in $\mathrm{CHO}$ cell line (Supplementary Table 1). Glycosylation is a crucial factor in the targeting process for ERT of lysosomal enzymes, which is governed by receptor-mediated uptake. ${ }^{5-7}$ The data presented in Figure $1 \mathrm{~b}$ demonstrate that the uptake of idursulfase beta was occurred by M6PR-mediated manner. In addition, idursulfase beta exhibited faster time-dependent uptake into the patient fibroblasts (Figures 2a and b), which was consistent with good uptake kinetics value in normal fibroblasts (Table 1).

The IDS protein begins degradation of heparan sulfate and dermatan sulfate accumulated in lysosomes after uptaking. The GAG clearance of the two enzymes exhibited similar results in the experiment using the radioisotope ${ }^{35} \mathrm{~S}$-labeled GAGs (Figures $2 \mathrm{~d}$ and e). Idursulfase beta exhibited statistically significantly higher degradation activities in low-dose treatment $(<312 \mathrm{pm})$. The specific activity of idursulfase beta was still higher than that of idursulfase after uptaking (Supplementary Figure 2), as determined by in vitro specific activity. This result can be explained by differences in FGly content which is required for sulfate catalytic activity. Sulfatase activity with higher FGly content resulted in an improved clearance of intracellular GAGs. ${ }^{28}$ The FGly content of idursulfase beta $(79.40 \%)$ was significantly higher compared with idursulfase (68.12\%); therefore, idursulfase beta shows higher enzyme activity than idursulfase (Supplementary Table 1).

In vivo studies were performed to determine correlation with faster cell uptake and higher intracellular GAGs degradation of idursulfase beta. IDS protein levels in most of the tissues, except for the liver, revealed that the majority of the injected dose was less than $\sim 1 \%$ of the injected dose at $2 \mathrm{~h}$. The amount of idursulfase beta in the most organ tissues examined was higher than that of idursulfase, although it was just statistically meaningful in the kidney (Table 2). Anyway, this trend itself shows a certain correlation with the results in cellular uptake of both enzymes.

Organ distribution is influenced by various factors such as administration method, protein stability, sialic acid and M6P contents and monosaccharide contents of the protein. Two enzymes have sialic acid content of $18.94 \pm 0.28$ (idursulfase beta) and $20.08 \pm 0.06$ (idursulfase), respectively (Supplementary Table 2). The pharmacokinetics of glycoproteins depends on sialic acid capping on the end sites of $\mathrm{N}$-linked glycans. ${ }^{29}$ The in vivo half-lives of non-sialylated glycoproteins decreases significantly because terminal galactose (Gal) residues are recognized by asialoglycoprotein receptors expressed in hepatocytes. ${ }^{30,31}$ The IDS protein contains highly sialylated glycans, which prolong the circulating half-life of the enzyme. Sialylation of IDS reduced uptake by hepatic receptors. ${ }^{3,11,32}$ These two enzymes have similar sialic acid contents, M6P contents (Supplementary Table 1) $)^{17}$ and similar monosaccharide composition (Supplementary Table 3).

Comparing the long-term efficacy of the two enzymes, the reductions in urine GAGs were similar (Figure 3a), but tissue GAGs levels exhibited slight differences (Figure 3b). Kidney and lung GAGs exhibited a statistically significantly greater reduction in the idursulfase beta-treated group. The long-term treatment of enzymes improved the bone disease of IDS KO mice (Figures $3 \mathrm{c}$ and d). Skeletal abnormalities in Hunter syndrome patients are manifest as the thickening of most long bones, ${ }^{33,34}$ and this deformation eventually results in the loss of mobility. ERT improves this problem and lead to better quality of life. ${ }^{35}$ Idursulfase beta and idursulfase treatments resulted in significant improvements in 6-MWT distances in attenuated MPS II patients. ${ }^{1,2}$

A phase I/II clinical trial showed that no newly detected IgG antibodies to idursulfase beta or anti-idursulfase IgE antibodies were detected at any time, ${ }^{1}$ but the immunogenicity of idursulfase reported about $50 \%$ in the literatures. ${ }^{2,3}$ In the current in vivo study, high concentrations of anti-drug IgG antibodies were detected in the idursulfase-treated group $(\sim 75 \%$, six of eight mice) but were not detected in the idursulfase beta group. When we checked neutralizing effect of these antibodies, there was no effect on cell uptake of the enzyme, but two of six antibodies (KO-2 and KO-5) reduced catalytic activity by approximately 36 and $72 \%$, respectively (Figures $4 \mathrm{c}$ and d). These antibodies to idursulfase may be the result of specific immunogenic epitopes or other factors not present in idursulfase beta. The antibody titer to idursulfase was always high in the ADA assays (Supplementary Figure 4).

The formation of antibodies is induced by various factors, such as the immune condition of the patient, the structure and characteristics of the infused protein drug, the administration route and the duration of treatment. ${ }^{36}$ Characteristics of the protein, such as glycosylation, oxidation and aggregation, may be affected by manufacturing process: protein production, purification, formulation, storage and handling. ${ }^{37,38}$ Culture conditions of both enzymes are different, idursulfase beta is produced in a serum free condition but idursulfase is known to be produced with serum. When we compared the degree of aggregation of the two enzymes by analytical ultra-centrifugation analysis, a reduced amount of aggregates was detected for idursulfase beta, but the aggregation of idursulfase did not appear to affect antibody formation in IDS-tolerant mice (Figure 4b). In addition, in glycan structure analysis, idursulfase beta contained only small amounts of high-mannose type and hybrid-type glycans compared with idursulfase. The fraction of complex-type glycans in idursulfase was characterized by an increased proportion of glycans with higher antennarity and sialic acid substitution. High-mannose glycan 
structures are also considered immunogenic factors due to uptake by the mannose receptor expressed on macrophages, endothelial cells and dendritic cells, and the presentation of the antigen by major histocompatibility complexes (MHCs) of these cells. ${ }^{39}$ Further study is needed to elucidate the immunogenicity of idursulfase beta to treat MPS II patient naive to ERT treatment.

We compared the biochemical characteristics and the in vitro and in vivo efficacies of idursulfase beta and idursulfase in Hunter patient fibroblasts and IDS KO mice. These enzymes have the same amino acid sequence but slightly different characteristics. In preclinical and clinical trials, the enzymes exhibited good efficacy as ERT drugs, decreasing urine GAGs level and improving 6-MWT distance. Therefore, we expect that these studies will facilitate further research on MPS II patients to investigate a correlation between clinical and preclinical studies and to develop other ERT drugs.

\section{CONFLICT OF INTEREST}

The authors declare no conflict of interest.

\section{ACKNOWLEDGEMENTS}

This study was supported by the Green Cross Corporation. We thank Jieun Park and Haerim Jang for technical assistance.

1 Sohn, Y. B., Cho, S. Y., Park, S. W., Kim, S. J., Ko, A. R., Kwon, E. K. et al. Phase I/II clinical trial of enzyme replacement therapy with idursulfase beta in patients with Jmucopolysaccharidosis II (Hunter syndrome). Orphanet. J. Rare Dis. 8, 42 (2013).

2 Muenzer, J., Gucsavas-Calikoglu, M., McCandless, S. E., Schuetz, T. J. \& Kimura, A A phase I/II clinical trial of enzyme replacement therapy in mucopolysaccharidosis II (Hunter syndrome). Mol. Genet. Metab. 90, 329-337 (2007).

3 Muenzer, J., Wraith, J. E., Beck, M., Giugliani, R., Harmatz, P., Eng, C. M. et al. A phase II/III clinical study of enzyme replacement therapy with idursulfase in mucopolysaccharidosis II (Hunter syndrome). Genet. Med. 8, 465-473 (2006).

4 Bielicki, J., Freeman, C., Clements, P. R. \& Hopwood, J. J. Human liver iduronate-2sulphatase. Purification, characterization and catalytic properties. Biochem. J. 271, 75-86 (1990).

5 Ghosh, P., Dahms, N. M. \& Kornfeld, S. Mannose 6-phosphate receptors: new twists in the tale. Nat. Rev. Mol. Cell Biol. 4, 202-212 (2003).

6 Kornfeld, S. Structure and function of the mannose 6-phosphate/insulinlike growth factor II receptors. Annu. Rev. Biochem. 61, 307-330 (1992).

7 Kornfeld, S. \& Mellman, I. The biogenesis of lysosomes. Annu. Rev. Cell Biol. 5, 483-525 (1989).

8 Schmidt, B., Selmer, T., Ingendoh, A. \& von Figura, K. A novel amino acid modification in sulfatases that is defective in multiple sulfatase deficiency. Cell 82, 271-278 (1995).

9 Selmer, T., Hallmann, A., Schmidt, B., Sumper, M. \& von Figura, K. The evolutionary conservation of a novel protein modification, the conversion of cysteine to serinesemialdehyde in arylsulfatase from Volvox carteri. Eur. J. Biochem. 238, 341-345 (1996).

10 Dierks, T., Schmidt, B. \& von Figura, K. Conversion of cysteine to formylglycine: a protein modification in the endoplasmic reticulum. Proc. Natl Acad. Sci. USA 94, 11963-11968 (1997)

11 Millat, G., Froissart, R., Maire, I. \& Bozon, D. Characterization of iduronate sulphatase mutants affecting $\mathrm{N}$-glycosylation sites and the cysteine-84 residue. Biochem. J. 326, 243-247 (1997)

12 Garcia, A. R., DaCosta, J. M., Pan, J., Muenzer, J. \& Lamsa, J. C. Preclinical dose ranging studies for enzyme replacement therapy with idursulfase in a knock-out mouse model of MPS II. Mol. Genet. Metab. 91, 183-190 (2007).

13 Cho, S. Y., Lee, J., Ko, A. R., Kwak, M. J., Kim, S., Sohn, Y. B. et al. Effect of systemic high dose enzyme replacement therapy on the improvement of CNS defects in a mouse model of mucopolysaccharidosis type II. Orphanet. J. Rare Dis. 10, 141 (2015).

14 Burton, B. K. \& Whiteman, D. A. Incidence and timing of infusion-related reactions in patients with mucopolysaccharidosis type II (Hunter syndrome) on idursulfase therapy in the real-world setting: a perspective from the Hunter Outcome Survey (HOS). Mol. Genet. Metab. 103, 113-120 (2011).

15 Okuyama, T., Tanaka, A., Suzuki, Y., Ida, H., Tanaka, T., Cox, G. F. et al. Japan Elaprase Treatment (JET) study: idursulfase enzyme replacement therapy in adult patients with attenuated Hunter syndrome (Mucopolysaccharidosis II, MPS II). Mol. Genet. Metab. 99, 18-25 (2010).

16 Kim, J., Park, M. R., Kim, D. S., Lee, J. O., Maeng, S. H., Cho, S. Y. et al. IgE-mediated anaphylaxis and allergic reactions to idursulfase in patients with Hunter syndrome. Allergy 68, 796-802 (2013).
17 Chung, Y. K., Sohn, Y. B., Sohn, J. M., Lee, J., Chang, M. S., Kwun, Y. et al. A biochemical and physicochemical comparison of two recombinant enzymes used for enzyme replacement therapies of hunter syndrome. Glycoconj. J. 31, 309-315 (2014).

18 Sohn, Y. B., Ki, C. S., Kim, C. H., Ko, A. R., Yook, Y. J., Lee, S. J. et al. Identification of 11 novel mutations in 49 Korean patients with mucopolysaccharidosis type II. Clin. Genet. 81, 185-190 (2012).

19 Jung, S. C., Park, E. S., Choi, E. N., Kim, C. H., Kim, S. J. \& Jin, D. K. Characterization of a novel mucopolysaccharidosis type II mouse model and recombinant AAV2/8 vectormediated gene therapy. Mol. Cells 30, 13-18 (2010).

20 Baldo, G., Quoos Mayer, F., Burin, M., Carrillo-Farga, J., Matte, U. \& Giugliani, R. Recombinant encapsulated cells overexpressing alpha-L-iduronidase correct enzyme deficiency in human mucopolysaccharidosis type I cells. Cells Tissues Organs 195, 323-329 (2012).

21 Zhao, K. W. \& Neufeld, E. F. Purification and characterization of recombinant human alpha-N-acetylglucosaminidase secreted by Chinese hamster ovary cells. Protein Exp. Purif. 19, 202-211 (2000).

22 Tippin, B. L., Troitskaya, L., Kan, S. H., Todd, A. K., Le, S. Q. \& Dickson, P. I. Biochemical characterization of fluorescent-labeled recombinant human alpha-Liduronidase in vitro. Biotechnol. Appl. Biochem. 58, 391-396 (2011).

23 Bjornsson, S. Simultaneous preparation and quantitation of proteoglycans by precipitation with alcian blue. Anal. Biochem. 210, 282-291 (1993).

24 Kobayashi, H., Carbonaro, D., Pepper, K., Petersen, D., Ge, S., Jackson, H. et al. Neonatal gene therapy of MPS I mice by intravenous injection of a lentiviral vector. Mol. Ther. 11, 776-789 (2005).

25 Hermeling, S., Aranha, L., Damen, J. M., Slijper, M., Schellekens, H., Crommelin, D. J. et al. Structural characterization and immunogenicity in wild-type and immune tolerant mice of degraded recombinant human interferon alpha2b. Pharm. Res. 22, 1997-2006 (2005)

26 Tomatsu, S., Gutierrez, M., Nishioka, T., Yamada, M., Yamada, M., Tosaka, Y. et al. Development of MPS IVA mouse (Galnstm(hC79S.mC76S)slu) tolerant to human $\mathrm{N}$-acetylgalactosamine-6-sulfate sulfatase. Hum. Mol. Genet. 14, 3321-3335 (2005).

$27 \mathrm{Bi}$, V., Jawa, V., Joubert, M. K., Kaliyaperumal, A., Eakin, C., Richmond, K. et al. Development of a human antibody tolerant mouse model to assess the immunogenicity risk due to aggregated biotherapeutics. J. Pharm. Sci. 102, 3545-3555 (2013).

28 Fraldi, A., Biffi, A., Lombardi, A., Visigalli, I., Pepe, S., Settembre, C. et al. SUMF1 enhances sulfatase activities in vivo in five sulfatase deficiencies. Biochem. J. 403, 305-312 (2007).

29 Ngantung, F. A., Miller, P. G., Brushett, F. R., Tang, G. L. \& Wang, D. I. RNA interference of sialidase improves glycoprotein sialic acid content consistency. Biotechnol. Bioeng. 95, 106-119 (2006).

30 Fukuda, M. N., Sasaki, H., Lopez, L. \& Fukuda, M. Survival of recombinant erythropoietin in the circulation: the role of carbohydrates. Blood 73, 84-89 (1989).

31 Weiss, P. \& Ashwell, G. The asialoglycoprotein receptor: properties and modulation by ligand. Prog. Clin. Biol. Res. 300, 169-184 (1989).

32 Jones, A. J., Papac, D. I., Chin, E. H., Keck, R., Baughman, S. A., Lin, Y. S. et al. Selective clearance of glycoforms of a complex glycoprotein pharmaceutical caused by terminal $\mathrm{N}$-acetylglucosamine is similar in humans and cynomolgus monkeys. Glycobiology 17, 529-540 (2007).

33 Scarpa, M. in GeneReviews (R) (eds Pagon R. A. et al.) (University of Washington, Seattle, Seattle, WA, USA, 1993-2016)

34 Tomatsu, S., Almeciga-Diaz, C. J., Montano, A. M., Yabe, H., Tanaka, A., Dung, V. C. et al. Therapies for the bone in mucopolysaccharidoses. Mol. Genet. Metab. 114, 94-109 (2015)

35 Raluy-Callado, M., Chen, W. H., Whiteman, D. A., Fang, J. \& Wiklund, I. The impact of Hunter syndrome (mucopolysaccharidosis type II) on health-related quality of life. Orphanet. J. Rare Dis. 8, 101 (2013)

36 Schellekens, H. Factors influencing the immunogenicity of therapeutic proteins. Nephrol. Dial. Transplant. 20 (Suppl 6): vi3-vi9 (2005).

37 Sharma, B. Immunogenicity of therapeutic proteins. Part 1: impact of product handling. Biotechnol. Adv. 25, 310-317 (2007).

38 Sharma, B. Immunogenicity of therapeutic proteins. Part 3: impact of manufacturing changes. Biotechnol. Adv. 25, 325-331 (2007).

39 Jefferis, R. Glycosylation as a strategy to improve antibody-based therapeutics. Nat. Rev. Drug Discov. 8, 226-234 (2009).

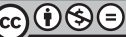

This work is licensed under a Creative Commons Attribution-NonCommercial-NoDerivs $\quad 4.0$ International License. The images or other third party material in this article are included in the article's Creative Commons license, unless indicated otherwise in the credit line; if the material is not included under the Creative Commons license, users will need to obtain permission from the license holder to reproduce the material. To view a copy of this license, visit http://creativecommons.org/licenses/bync-nd/4.0/

(C) The Author(s) 2017

Supplementary Information accompanies the paper on Journal of Human Genetics website (http://www.nature.com/jhg) 